\title{
Managerial Competencies in Hotel Industry
}

\author{
P. Cech \& M.Beranek \\ Institute of Hospitality Management in Prague, Czech Republic
}

M.Tomastik

Tomas Bata University in Zlin, Czech Republic

\begin{abstract}
Nowadays companies try to find a comparative advantage which enables them to gain profit. One possible way to make a profit is to use high-quality human resources, including competent managers, at all managerial levels. This is the main reason for managers, as well as research workers working in a managerial field, attaching great importance to managerial competencies. This trend also applies to the service sector in the Czech Republic, and within this framework, for companies engaged in lodging and boarding services. In this article the authors have focused on managerial competencies that reflect the opinion of commercial sphere. Part of this article is concerned with extensive research dealing with assessment of the significance of the chosen competencies and their relationship to changes, risk, and managers' ethics, in the hotel industry. The research outcomes are described in the last part of this article.
\end{abstract}

KEYWORD: managerial competencies; management; knowledge; capability

\section{INSTRUCTION}

The current entrepreneurial environment places great demands on the people who are employed in company management at all levels. In the first instance, managers are expected to have high-quality general education, special professional qualifications in a given field of the company's activity, problem solving abilities, ability to prevent problem formation, and non-conventional creative thinking in favour of company development for the future. To succeed in a large, competitive market environment, a hotel or hotel chain must primarily be managed competently, not only at the highest level but throughout the organisation, to the middle and lowest levels.

\section{CONCEPTION OF MANAGERIAL COMPETENCIES}

Managerial competencies express the claims on managers that allow them to enhance the company's competitiveness and its development; a manager's potential is the cornerstone. Drucker (1973) emphasises that a manager is responsible for meeting the targets of an organisation, unit, or team he/she runs, and usually he/she participates significantly in the accomplishment of these objectives, and in securing the prerequisites to their accomplishment.
The manager firstly plans, organises and controls the work of his/her workmates. A job competency is an underlying characteristic of a person in that it may be a motive, trait, and skill, aspect of one's self-image or social role, or a body of knowledge which he/she uses. The existence and possession of these characteristics may or not be known to the person. In this sense, the characteristics may be unconscious aspects of the person. Because job competencies are underlying characteristics, they can be said to be generic. A generic characteristic may be apparent in many forms of behaviour, or a wide variety of different actions (Mintzberg 1973).

The outstanding author who has contributed significantly to the development of theory dealing with competencies is undoubtedly Boyatzis. Boyatzis (1982) claims that a competency is an underlying characteristic of the person that leads to, or causes, effective or superior performance. He asserts that a competency can be characterised as the capability of a human being to act according to work requirements that are produced by an organisation's environment. Respecting it means producing desired results. At the same time, a person's capabilities, requirements corresponding the working position, and performance, become key aspects. At the core of every manager's job is the requirement to make things happen toward a goal or consistent with a plan. Managers need to set goals and initiate actions to achieve them. 
Managerial competencies can be described as a set of characteristics and indicators whose essence is comprised of knowledge, experience, needs, motives, values, attitudes, and skills (Kovács 2009). Generally, it is possible to understand competencies as skills to perform some activities, to be able to perform them or to be qualified to perform them (Kubeš et al. 2004). According to Häuser (2008), it is important in the 21st century for managers to cope with the management of changes as well as with the application of internal strategies to form a potential of long-term success for a company. Molnar \& Spingl (2008) state the concept of a professional in context of Competitive Intelligence. They underline the importance not only of knowledge, but also the managers' qualities (instinctive character, creativity, ability of argumentation, entrepreneurial patience and competitiveness), and also place some emphasis on communication skills.

There are a number of distinguishing managerial competencies and definitions. In this research the authors worked on managers' opinions formed from their own practice. The authors were especially interested in the following: planning skills and capabilities, organisational skills, managing people, leadership, communication, negotiation, decision making, problem solving, and working in an international environment. At the same time the authors tried to ascertain how important the respondents believed a managers' charisma and their relationship to changes, risk, and ethics to be.

\section{RESEARCH METHODOLOGY}

A basic data file of our research embodied all managers (at the highest level, at middle and the lowest level) who are employed in hotels or hotel chains in the Czech Republic. The objective of our research was to find out how important individual competencies are for managers, and if and how the level of management influences the evaluation of importance of these managerial competencies. In this article the authors decided to focus only on the two competencies which were chosen by the respondents as the most important.

A questionnaire survey, carried out from November 2013 to May 2014, was chosen as the research method. The necessary data were acquired via inquirers who carried out the questionnaire survey within the Czech Republic. From a total number of 820 questionnaires, the respondents filled in a total of 558 questionnaires, and these respondents create a selective complex of managers. The rate of return of the questionnaires was $68.05 \%$.

\section{THE RESEARCH OUTCOMES: QUESTIONNAIRE SURVEY EVALUATION}

In Figures 1-2, the hotel managers' and managers of hotel chains' competencies evaluation from the whole selective complex are represented. The competencies that are essential for a managers' work were evaluated at a level of significance 1-10 (1 - the least important, 10 - the most important).

Legend to Figure 1: A - Knowledge of planning techniques and ability to apply them in practice; B Organisational techniques, knowledge, and the ability to apply them in practice; C - Capability to manage people; D - Capability to create and purvey visions; E - Leadership; F - Communication skills; $\mathrm{G}$ - Negotiation skills; H - Knowledge of decision making techniques, and ability to apply them in practice; I - Problem solving capability; J - Selfeducation capability.

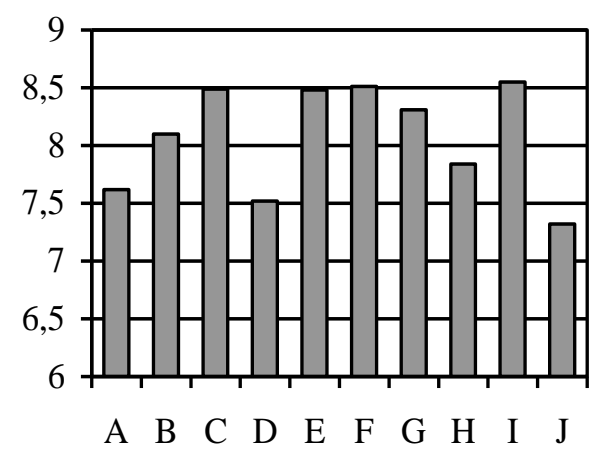

Figure 1. Managerial competencies evaluation - part 1.

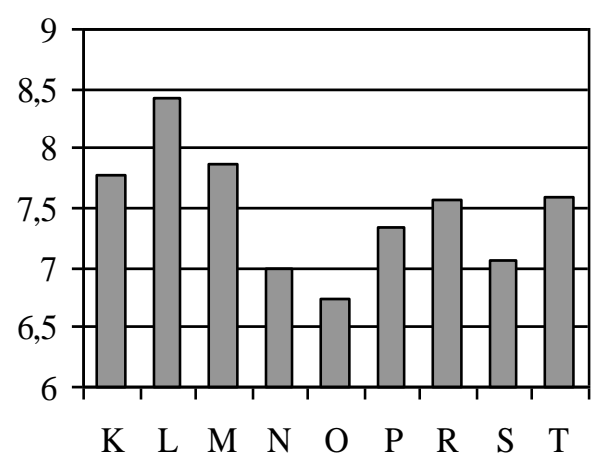

Figure 2. Managerial competencies evaluation - part 2.

Legend to Figure 2: K - Capability to manage the performance of others; L - Capability to deal with people; M - Capability of proactive treating; $\mathrm{N}$ - Capability to work in an international environment; $\mathrm{O}$-Capability to manage an international team; P-Charisma, R-Positive relationship to changes; $\mathrm{S}$ - Positive relationship to risk; $\mathrm{T}$ - Positive relationship to ethics.

The following competencies were identified by the respondents as the most important: Problem solving capability, Leadership, and Capability to 
deal with people. As for the least important, the respondents selected: Self-education capability, Capability to work in an international environment, and Capability to manage an international team. The authors find it interesting that a positive relationship to changes and ethics were assessed as more important than Charisma and Positive relationship to risk.

Figure 3-4 represents how the above stated competencies were evaluated by top managers (1st column), managers at middle level (2nd column) and managers at the lowest level of management (3rd column).

Legend to Figure 3: A - Knowledge of planning techniques and ability to apply them in practice; $\mathrm{B}$ - Organisational techniques, knowledge, and the ability to apply them in practice; C - Capability to manage people; D - Capability to create and purvey visions; E - Leadership; F - Communication skills; G - Negotiation skills; H - Knowledge of decision making techniques, and ability to apply them in practice; I - Problem solving capability; J - Selfeducation capability.

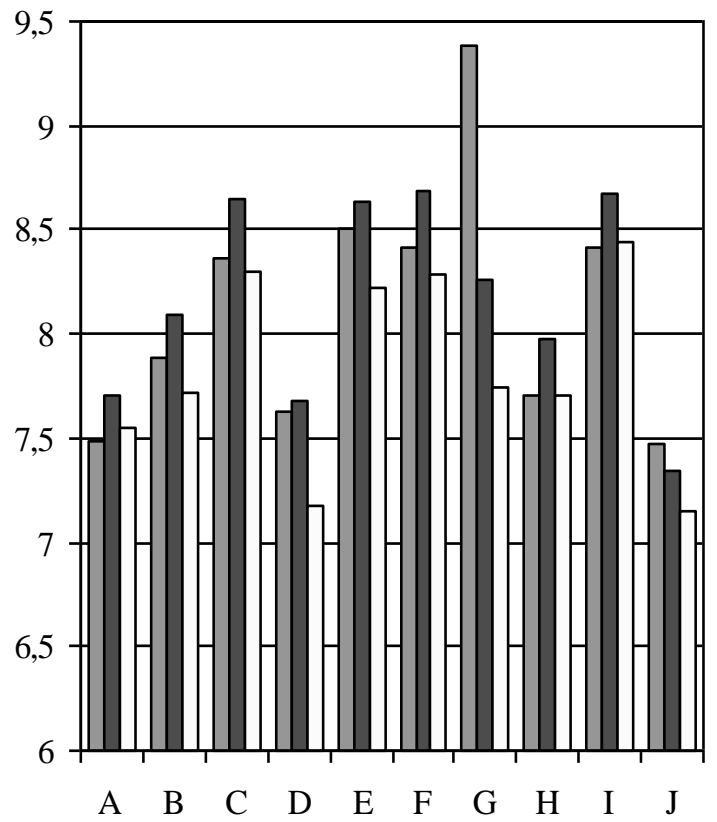

Figure 3. Managerial competencies according to a level of management - part 1.

Legend to Figure 4: K - Capability to manage the performance of others; L - Capability to deal with people; M-Capability of proactive treating; $\mathrm{N}$ - Capability to work in an international environment; $\mathrm{O}$-Capability to manage an international team; $\mathrm{P}$-Charisma, $\mathrm{R}$ - Positive relationship to changes; $\mathrm{S}$ - Positive relationship to risk; T - Positive relationship to ethics.

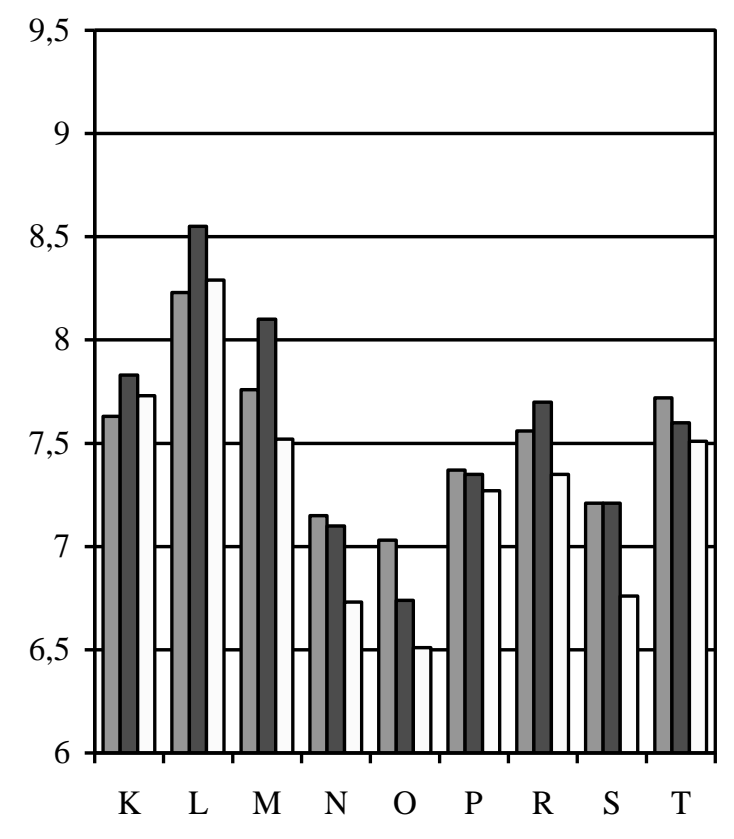

Figure 4. Managerial competencies according to a level of management - part 2.

While comparing the evaluation of the most important competencies for managers at different levels of management, it is possible to state that top managers consider negotiation skills to be the most significant. Managers working at the middle level of management did not evaluate such competence so significantly. They placed emphasis on the capability to deal with people, to manage them, leadership, communication skills, and problem solving capability. Managers at the lowest level of management especially highlighted problem solving capability, the capability to manage people, communication skills, leadership, and capability to deal with people. Top managers placed greater emphasis on the capability to work in an international environment, and especially on the capability to manage an international team, than managers working at lower levels.

\section{CONCLUSION}

This article deals with selected managerial competencies of hotel managers and managers of hotel chains at all levels of management. In their research the authors tested individual managerial competencies and tried to discover if and how they are significant for them and if and how this fact influences a level of management. The authors have found out that the level of management influences the evaluation of individual competencies. This research will contribute to the effective training/preparation of hotel managers and managers of hotel chains at individual levels of management, as well as contributing to the development of selected competencies. Differential development of 
managers in this way may contribute to the total entrepreneurial success of a hotel or a hotel chain. The research outcomes will be used to adapt the study programmes at the Institute of Hospitality Management in Prague, which is aimed at the education of managers in the hotel industry.

\section{REFERENCES}

[1] Boyatzis, R. 1982 Competent manager: a model for effective performance. New York: John Wiley \& Sons.
[2] Drucker, P.F. 1973. Management: Task, Responsibilities, Practices. New York: Harper \& Row.

[3] Häuser, S. 2008. Strategie dlouhodobé úspěšnosti. Moderní ŕízení 9: 87-95.

[4] Kovács, J. 2009. Kompetentní manažer procesu. Praha: Wolters Kluwer ČR.

[5] Kubeš, M. et al. 2004. Manažerské kompetence: Způsobilosti výjimečných manažerů. Praha: Grada.

[6] Mintzberg, H. 1973. The nature of managerial work. New York: Harper \& Row.

[7] Molnár, Z. \& Špingl, I. 2008. Potřeba, místo a úloha CI profesionála $\mathrm{V}$ organizaci. In Systems Integration; 16th International Conference on Systems Integration, Prague, 10-11 June 2008. Praha: CSSI. 